\title{
Traffic tracers in a suburban location in northern Spain: relationship between carbonaceous fraction and metals
}

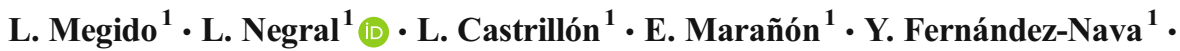 \\ B. Suárez-Peña ${ }^{2}$
}

Received: 26 August 2015 / Accepted: 10 December 2015 / Published online: 22 January 2016

(C) The Author(s) 2016. This article is published with open access at Springerlink.com

\begin{abstract}
PM10 and black smoke were monitored at a suburban sampling station located in the northern Spanish city of Gijón. Thirty-two metals and total carbon (TC) (i.e., organic carbon (OC) and elemental carbon (EC)) were analyzed over a year. The study of air-mass origin based on 5-day back trajectories was carried out to assess its influence on the recovery data. Different strategies were implemented to infer the influence of traffic in the area. On average, TC accounted for $29 \%$ of the PM10 fraction, with OC forming $77 \%$ of this TC. The influence of traffic was clearly reduced during intense Atlantic advection episodes, when $\mathrm{OC}$ and $\mathrm{EC}$ decreased up to 0.39 and $0.22 \mu \mathrm{g} \mathrm{C} / \mathrm{m}^{3}$, respectively. In contrast, the highest values were reported during regional episodes, exceeding $10 \mu \mathrm{g}$ $\mathrm{C} / \mathrm{m}^{3}$ of $\mathrm{OC}$ and $2 \mu \mathrm{g} \mathrm{C} / \mathrm{m}^{3}$ of EC. The correlation between $\mathrm{EC}$ and $\mathrm{OC}$ was found to notably improve when considering the days with high traffic flow (from $R^{2}=0.46$ to $R^{2}=0.74$ ). This pattern was also reproduced by black smoke and EC (from $R^{2}=0.49$ to $R^{2}=0.59$ ). $\mathrm{Cu}$ and $\mathrm{Sn}$ were found to be reliable traffic tracers given their high dependence on EC ( $R^{2}=0.82$ and $R^{2}=0.79$, respectively). Nevertheless, $\mathrm{Sn}, \mathrm{Ba}$,
\end{abstract}

Responsible editor: Constantini Samara

Electronic supplementary material The online version of this article (doi:10.1007/s11356-015-5955-8) contains supplementary material, which is available to authorized users.

L. Negral

negralluis@uniovi.es

1 Department of Chemical and Environmental Engineering, University Institute of Industrial Technology of Asturias, University of Oviedo, Gijón Campus, 33203 Gijón, Spain

2 Department of Materials Science and Metallurgiscal Engineering, Polytechnic School of Engineering, University of Oviedo, Gijón Campus, 33203 Gijón, Spain and $\mathrm{Sb}$ showed a better correlation with $\mathrm{Cu}$ than $\mathrm{EC}$, suggesting a common origin. In the case of $\mathrm{Sn}, R^{2}$ improved from 0.79 to 0.91 . The $\mathrm{Cu} / \mathrm{Sb}$ ratio had a mean value of 6.6 which agrees with diagnostic criterions for brake wear particles. The relationships and ratios between $\mathrm{EC}, \mathrm{Cu}, \mathrm{Sb}, \mathrm{Sn}, \mathrm{Ba}$, and $\mathrm{Bi}$ pointed out to non-exhaust emissions, playing a significant role in the chemical composition of PM10. Brake wear was presented as the most likely origin for $\mathrm{Cu}, \mathrm{Sb}$, and $\mathrm{Sn}$.

Keywords Air-mass origin · Brake wear · EUSAAR2 . Non-exhaust emissions · Particulate matter · Road traffic . Trace metals

\section{Introduction}

Different sources contribute to airborne particulate matter (PM). Certain chemical species have been scientifically proposed as tracers for road traffic, the presence of which in PM may differ depending on the type of vehicle engine and road surface abrasion (Sternbeck et al. 2002; Amato et al. 2009).

PM emissions involve carbon in different chemical and physical forms. Carbonaceous particles may account for the largest fraction of these emissions. Total carbon (TC) comprises of organic carbon (OC) and elemental carbon (EC). The latter is also called black carbon (BC), depending on the method employed in its determination. Typically, BC is determined by optical methods and EC using thermal analysis (Gelencsér 2004). OC comprises a major percentage of PM10. In contrast, the contribution of EC is somewhat lower (Negral et al. 2008). EC is a suitable indicator to assess the impact of traffic on PM (Minguillón et al. 2014). The origin of EC is exclusively primary, whereas OC may also have secondary origins (Salvador et al. 2007; Sánchez de la Campa et al. 2009; Minguillón et al. 2014). Furthermore, according to 
ISO 1993, black smoke (BS) is strongly light-absorbing particulate material mainly constituted by "soot," i.e., particulates that contain carbon in its elemental form. Both BS and EC reflect the primary contribution of incomplete combustion emissions to PM (Gelencsér 2004). EC has been specifically defined as a marker for diesel exhaust (Sharma et al. 2014); therefore, abatement strategies may be focused on controlling diesel traffic emissions (Harrison and Yin 2008). Some studies showed EC as an appropriate indicator for traffic measures on air quality suggesting traffic volume, composition, and congestion as factors to control its emissions (Keuken et al. 2012).

Non-exhaust emissions (i.e., PM from brake wear, tire wear, road abrasion, and road dust resuspension) are raised in relevance due to the forthcoming reduction of exhaust pollutants (Thorpe and Harrison 2008; Fuzzi et al. 2015). Some metals have been related to non-exhaust emissions originating from road traffic using different approaches. Traffic tracers can be identified by comparing the levels of chemical elements at traffic sites and/or using source apportionment analysis. Querol et al. (2007) identified $\mathrm{Cu}-\mathrm{Sb}$ as tracers of brake abrasion as their levels were relatively high in urban areas of Spain. Minguillón et al. (2014) studied trace and major elements in PM10 in different areas in Barcelona, finding higher concentrations of $\mathrm{Ba}, \mathrm{Cr}, \mathrm{Cu}, \mathrm{Fe}, \mathrm{Mo}, \mathrm{Zn}, \mathrm{Mn}, \mathrm{Pb}$, $\mathrm{Sn}$, and $\mathrm{Zr}$ at traffic sites rather than in rural and urban background locations. Hueglin et al. (2005) found increasing values of several metals from urban kerbside to urban backgrounds, near-city and rural sites, inferring traffic as the main source of them.

Another approach involves finding relationships between elements in order to prove a common origin in road traffic. Pérez et al. (2010) correlated mean daily BC levels with TC, $\mathrm{Ni}, \mathrm{Cu}, \mathrm{Fe}, \mathrm{Sn}$, and $\mathrm{Sb}$ to demonstrate their related source. Vehicle emissions depend on the location. As an example, brakes contain high metal concentrations that considerably vary between brands and countries (Sternbeck et al. 2002). According to the literature, the major source of $\mathrm{Cu}$ is brake wear. Hence, different ratios and correlations with this metal have been carried out in a number of studies to prove a common origin: $\mathrm{Fe} / \mathrm{Cu}, \mathrm{Ba} / \mathrm{Cu}, \mathrm{Sb} / \mathrm{Cu}, \mathrm{Sn} / \mathrm{Cu}$, and $\mathrm{Zn} / \mathrm{Cu}$ (Sternbeck et al. 2002; Querol et al. 2007; Amato et al. 2009; Pérez et al. 2010; Alves et al. 2015). These ratios vary depending on the sampling site. Grigoratos and Martini (2015) posed concerns regarding the potential adverse health effects of brake wear particles since they lie into diameters smaller than $100 \mathrm{~nm}$.

TC has been associated with vehicle exhaust emissions and metals with re-suspension of road dust originating from mechanical wear and degradation of tires, brakes, and pavement abrasion. The metals emitted by vehicles have generally been determined by direct measurements and dynamometer driving cycles simulating different backgrounds (Keuken et al. 2012). As conventional dynamometric tests do not reflect real emissions of traffic, studies have been carried out in road tunnels for a more realistic approach. Although, this strategy implies the loss of other emission sources (Pio et al. 2011; Alves et al. 2015).

In this study, the PM10 fraction and its chemical composition were monitored at a suburban area located in the northern Spanish city of Gijón. BS was also measured at this location throughout the same period. The aim was to find relationships between frequently described traffic tracers in a complex scenario with multiple sources. Special attention was paid to TC and several of the previously mentioned metals. Moreover, traffic was taken into account in order to determine whether its influence was reflected in the correlations between tracers and hence discriminate the origin of the collected particulate matter. In addition, air-mass origins were studied to associate them with the related pollutant load. The variety of strategies implemented to revise the experimental data and infer the impact of traffic in the sampling station may contribute to increase the state-of-the-art in non-exhaust emissions.

\section{Materials and methods}

\section{Study area}

The study area was located at the University Campus in Gijón (Spain), specifically at a suburban sampling station affected by irregular road-traffic intensity. Gijón is a coastal city in the shoreline of the Cantabrian Sea. It has an Atlantic climate characterized by moderate mean temperatures, abundant rainfall from winter to early spring, and seasonal winds. The Spanish National Meteorological Agency (AEMET) has recorded main meteorological parameters in the sampling area from October 2013. Before that month, another meteorological station located within a distance of $1.7 \mathrm{~km}$ from the air monitoring site supplied these parameters. According to the data provided by these stations, the temperature fluctuated between -2.2 and $30.0^{\circ} \mathrm{C}$, with a minimum mean value of $10.2^{\circ} \mathrm{C}$ and a maximum mean value of $19.0^{\circ} \mathrm{C}$, during the sampling period. The accumulated rainfall reached $977 \mathrm{~mm}$. Winds were detected up to $13 \mathrm{~m} / \mathrm{s}$. The hours of sunshine in 2013 and 2014 were 1756 and 1833, respectively.

The municipal area of Gijón had a population density of 1518 inhabitants $/ \mathrm{km}^{2}$ in 2014 (IDEPA 2014), although the urban zone (about $7.6 \%$ of the total municipal area) represents $90 \%$ of the population. The daily limit value of PM10 (50 $\mu \mathrm{g} /$ $\mathrm{m}^{3}$ ) has been exceeded at one of the local monitoring stations over the last few years. The sampling station received the influence of traffic from the university campus during the academic year and from the nearby N-632 trunk road. Several points of convergence for the region's population are connected to the city by this road. The Gijón Science and Technology Park, three educational centers, and the local 
hospital are the main nerve centers of the area. Other main anthropogenic pollution sources include harbor activities (19 million tons of goods handled at Port Authority quays and berths (Port of Gijón 2014)), a cement plant (clinker kiln production capacity of $1500 \mathrm{t} /$ day $)^{1}$, a coal power station (installed power of $903 \mathrm{MW})^{1}$, and a steel production factory (blast furnaces with production capacity of 4.5 million tons a year $)^{1}$.

\section{Procedure}

\section{Gravimetric determination of PM10}

PM10 samples were collected daily from 11 July 2013 to 31 July 2014 using a high-volume sampler MCV CAV-A/MSb $\left(30 \mathrm{~m}^{3} / \mathrm{h}\right)$ for subsequent gravimetric determination. A microbalance with a resolution of $0.01 \mathrm{mg}$ was used for this purpose. The sampler was placed at a height of $3 \mathrm{~m}$, which is normal practice in the Spanish Air Quality Monitoring Network, and it was in accordance with the requirements set by the European Commission (2008). The 150-mm-diameter filters were made of glass microfiber (MCV GF1-150) and quartz microfiber (Pallflex-Tissue Quartz 2500QAT-UP). The latter had superior chemical purity and low content in trace organics obtained by a heat treatment during their manufacturing process. Thus, they produce less interference on chemical determinations (EN 12341:1998). Fifty-two samples were collected over this matrix.

\section{Analysis of chemical species}

PM10 samples collected on quartz microfiber filters were digested by $\mathrm{HF}, \mathrm{HNO}_{3}$, and $\mathrm{HClO}_{4}$ for metal extraction, as in a previous study (Negral et al. 2008). Afterward, thirty-two chemical species were determined by inductively coupled plasma mass spectrometry (ICP-MS). The same procedure was followed with blank filters and reference material from the National Institute of Standards and Technology (NIST), i.e., Standard Reference Material ${ }^{\circledR}$ 1648a (Urban Particulate Matter). Errors were mostly kept below $10 \%$.

\section{Measurement of organic and elemental carbon}

Thermal-optical reflectance/transmittance methods (TOR/ TOT) are used for total carbon quantification. These methods are based on the volatilization and oxidation of carbon-containing particles at different temperatures and oxidation conditions. Adsorption of volatile organic species or volatilization losses may lead to overestimation or underestimation of TC (Gelencsér 2004). Moreover, some thermal

\footnotetext{
${ }^{1}$ Information available at The European Pollutant Release and Transfer Register (E-PRTR)
}

evolution protocols exist (e.g., IMPROVE, NIOSH, EUSAAR2), which adds difficulty when comparing TC results with others from literature (Vodička et al. 2015).

In the present study, the EUSAAR2 thermal evolution protocol was employed to determine OC and EC (limit of quantification of $0.1 \mu \mathrm{g} \mathrm{C} / \mathrm{m}^{3}$ ). The following methodology was performed: a defined area of the sampling filter was cut and placed in the instrument's oven, previously purged with helium. Initially, the temperature of the oven increased up to a first maximum $\left(650^{\circ} \mathrm{C}\right)$. The $\mathrm{OC}$ was volatilized or charred in/on the filter and pyrolytic carbon (PC) was formed. Then, the oven cools and a second temperature ramp started (up to $\left.850^{\circ} \mathrm{C}\right) . \mathrm{CO}_{2}$ was formed by the oxidation of EC and PC. All gases released during the process were brought into a manganese dioxide furnace where organic vapors were oxidized to $\mathrm{CO}_{2} . \mathrm{CO}_{2}$ was mixed with $\mathrm{H}_{2}$ and carried with $\mathrm{He}$ through a heated $\mathrm{Ni}$ catalyst. The Ni catalyst reduced the $\mathrm{CO}_{2}$ to methane. Then, the latter was measured using a flame ionization detector (FID). Internal and external carbon standards were used for calibration. The burning process of organic carbon to elemental was corrected automatically by optical transmittance (TOT). Therefore, underestimation of OC and the corresponding overestimation of EC were avoided. The temperature set points and residence times of the EUSAAR2 protocol were provided by Cavalli et al. (2010). These researchers described this protocol regarding potential European standard procedures to measure the carbonaceous aerosol fraction.

\section{Determination of black smoke}

BS was also sampled daily throughout the same period using a low-volume captor CPV-8D/A ( $2 \mathrm{~m}^{3} /$ day $)$ and Whatman No. 1 filters (47-mm diameter). BS was determined using an EEL Model 43D Digital Smokestain Reflectometer. The percentage of reflectance produced by the sampling stain was determined by the detector and then related to BS concentration or the absorption coefficient $(\alpha)$ by the procedures of the Organization for Economic Cooperation and Development (OECD) method (OECD 1964) or the ISO 1993 standard (ISO 1993), respectively.

\section{Air-mass origins}

The HYSPLIT Model developed at the NOAA Air Resources Laboratory (Draxler and Hess 1997) was run to calculate 120-h isentropic back trajectories at three different heights $(750,1500$, and $2500 \mathrm{~m}$ above sea level) in order to catalog air-mass origins at the sampling station $\left(43^{\circ} 31^{\prime} 23^{\prime \prime} \mathrm{N}, 5^{\circ} 37^{\prime}\right.$ $16^{\prime \prime} \mathrm{W}$ ) according to eight different sectors (Fig. 1): Northern Atlantic (AN), North-western Atlantic (ANW), Western Atlantic (AW), South-western Atlantic (ASW), Northern African (NAF), Mediterranean (ME), European (EU), and Regional (RE). 
Fig. 1 Classification of air-mass origins: Northern Atlantic (AN); European (EU); Mediterranean (ME); Northern African (NAF); South-western Atlantic (ASW); Western Atlantic (AW); Northwestern Atlantic (ANW); and Regional (RE)

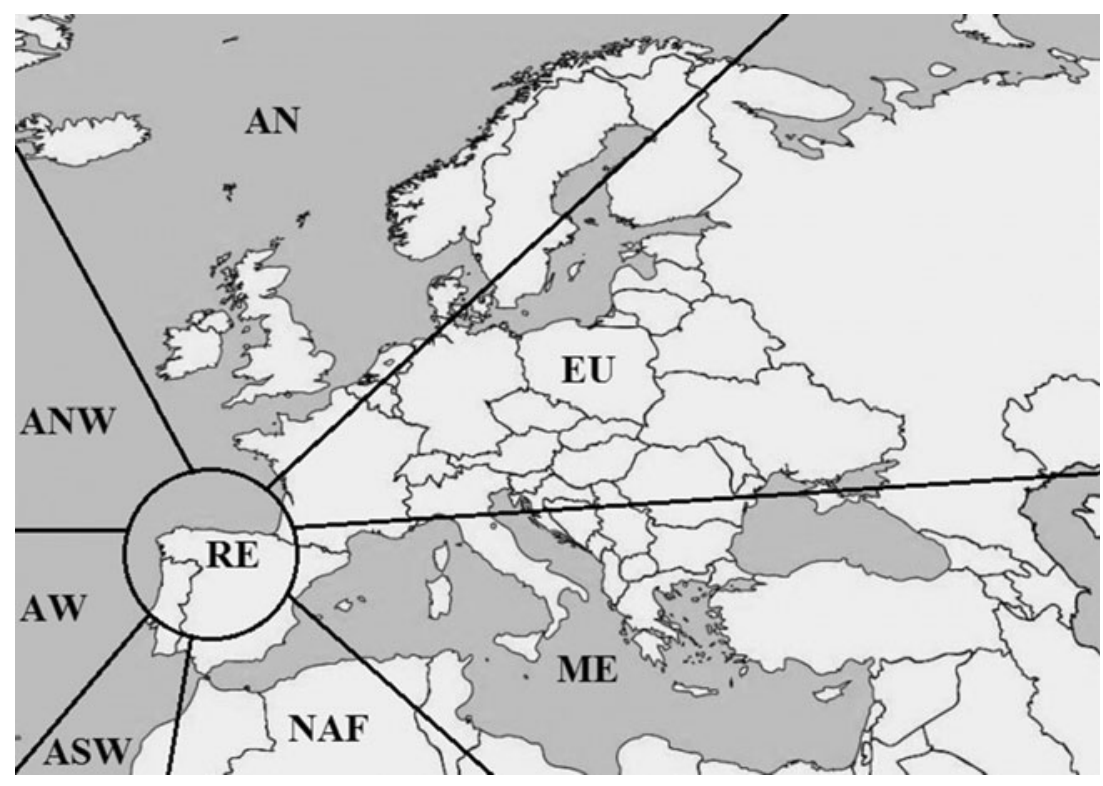

\section{Results and discussion}

\section{PM10 levels}

Throughout the entire sampling period, PM10 levels were in the range of 4.7-69.5 $\mu \mathrm{g} P M 10 / \mathrm{m}^{3}$. The mean value was 19.1 $\pm 10.1 \mu \mathrm{g}$ PM10 $/ \mathrm{m}^{3}$ ( $n=375$ samples), which agreed with the urban annual mean levels (9-23 $\mu \mathrm{g}$ PM $10 / \mathrm{m}^{3}$ in 2009) recorded in locations of northern Spain (Aldabe et al. 2011). Comparing these results with others across Europe, PM10 levels at the university campus in Gijón were in the same range as those from Central Europe, where they generally varied from 19 to $24 \mu \mathrm{g}$ PM10/m ${ }^{3}$ (Pey et al. 2009; Putaud et al. 2010; EEA 2014; Fuzzi et al. 2015).

Figure 2 shows a box plot of the PM10 levels. The distribution of the monthly PM10 levels was not symmetrical, being the median below the average in most cases. The daily limit value was exceeded on eight occasions. On those days, the precipitation rate was negligible (below $1.0 \mathrm{~mm}$ ). July and December 2013 and March 2014 presented the greatest dispersion of the recorded data (Fig. 2). In July 2013, air masses from AW, RE, and EU were predominant (Fig. 3), with high differences in the mean PM10 levels (AW 13.8 $\pm 1.8 \mu \mathrm{g} P M 10 / \mathrm{m}^{3} ; \mathrm{RE} 34.1 \pm 11.7 \mu \mathrm{g} \mathrm{PM} 10 / \mathrm{m}^{3}$, and $\mathrm{EU}$ $32.0 \pm 4.2 \mu \mathrm{g}$ PM10 $/ \mathrm{m}^{3}$, respectively), which explained the dispersion of the overall data during this month. Similarly, December 2013 and March 2014 were characterized by great variation between the mean PM10 levels recorded under the predominant air-mass origins: ANW and RE (Fig. 3). In December 2013, their averages were $19.0 \pm 10.5$ and 37.9 $\pm 6.6 \mu \mathrm{g} P M 10 / \mathrm{m}^{3}$, respectively. In March 2014, the mean PM10 was $14.7 \pm 6.2 \mu \mathrm{g}$ PM10 $/ \mathrm{m}^{3}$ under ANW and 27.4 $\pm 7.5 \mu \mathrm{g}$ PM10 $/ \mathrm{m}^{3}$ under RE episodes. Additionally, although EU air masses represented $13 \%$ of the days of March 2014
(Fig. 3), the average PM10 levels with these origins (55.9 $\pm 10.9 \mu \mathrm{g}$ PM10 $/ \mathrm{m}^{3}$ ) were well above the latter mentioned (i.e., ANW and RE). Seven exceedances of the daily limit occurred during these 3 months (Fig. 2). It should be noted that most of these levels occurred on weekdays, which points to traffic origin. Furthermore, the highest levels were under NAF $\left(59.9 \mu \mathrm{g}\right.$ PM10/m $\mathrm{m}^{3}$ on 12 December 2013) and EU (69.5 $\mu \mathrm{g}$ PM10/m ${ }^{3}$ on 13 March 2014 and $57.1 \mu \mathrm{g}$ PM10/ $\mathrm{m}^{3}$ on 14 March 2014) episodes. Therefore, although high PM10 levels were usually recorded under RE episodes, the maximum values were related to long transport processes in the absence of rainfall. Likewise, high PM10 levels were observed in winter at urban and traffic locations in northern Spain (Pamplona), which Aldabe et al. (2011) associated to low precipitation and dilution, as well as air-mass transport from Europe.

Some authors have found considerable variances in PM10 levels depending on the season (Umlauf et al. 2010; Schilirò et al. 2015). Sánchez de la Campa et al. (2009) explained the higher PM10 levels recorded in summer rather than in winter by the high photochemical activity during that period. However, the data of the present study showed no major differences. In the cold period (October-March), PM10 ranged between 4.7 and $69.5 \mu \mathrm{g} P M 10 / \mathrm{m}^{3}$, with an average of 19.3 $\pm 11.2 \mu \mathrm{g} \mathrm{PM} 10 / \mathrm{m}^{3}$, whereas the warm period (AprilSeptember) varied between 5.6 and $57.0 \mu \mathrm{g} P M 10 / \mathrm{m}^{3}$ and the average was $18.8 \pm 9.1 \mu \mathrm{g}$ PM10 $/ \mathrm{m}^{3}$. This was not surprising due to the region's Atlantic climate and low number of hours of sunshine (1756 h in 2013 and $1833 \mathrm{~h}$ in 2014).

\section{Carbonaceous particles}

Table 1 shows the seasonal variations of $\mathrm{EC}$ and $\mathrm{OC}$ and the $\mathrm{EC} / \mathrm{TC}$ ratio which was similar in warm and cold periods. 
Fig. 2 Box plot of PM10 levels showing outliers from 10th to 90th percentiles

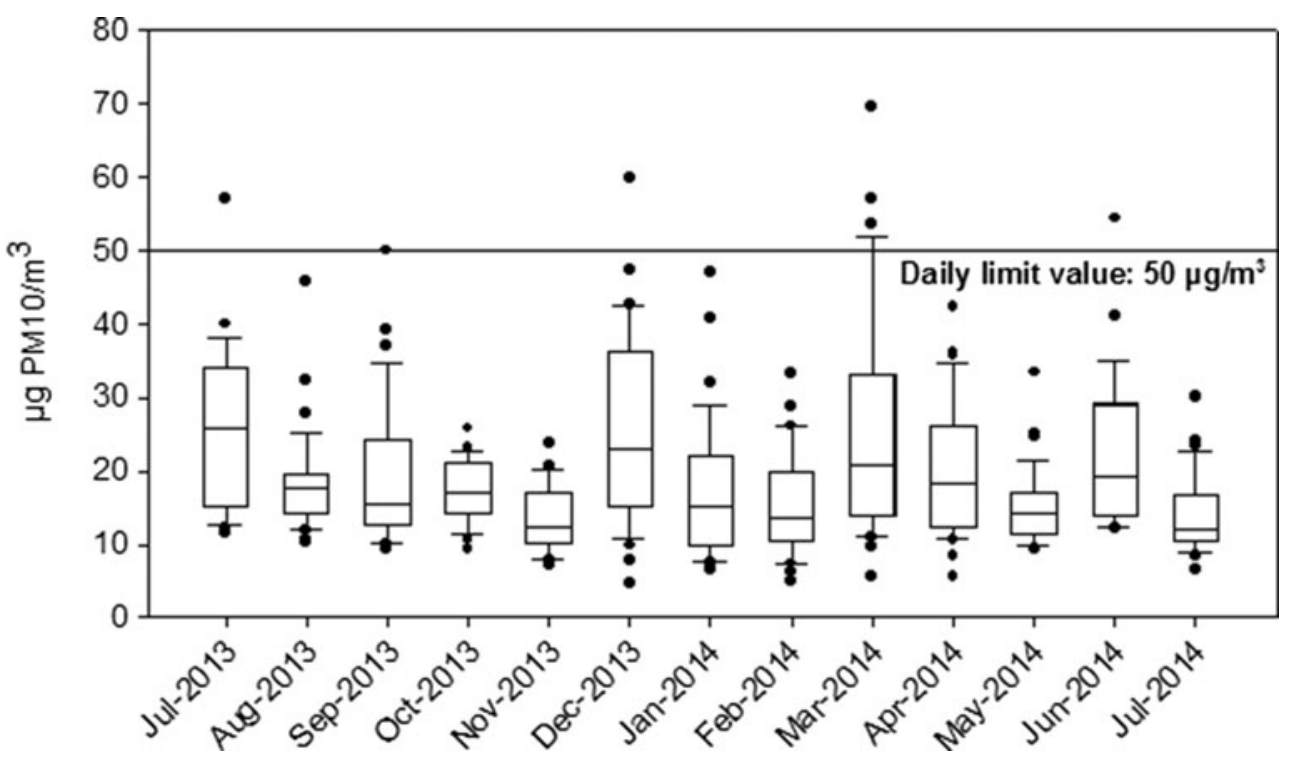

Greater OC levels are generally recorded in winter than in summer in most European locations, which is related to residential heating (i.e., biomass and fossil fuel combustion) and stagnant meteorological conditions (Fuzzi et al. 2015). Indeed, the maximum EC concentration $\left(4.96 \mu \mathrm{g} \mathrm{C} / \mathrm{m}^{3}\right)$ was observed during the cold period. The variability in EC, OC, and precipitation during the sampling period is shown in Fig. 4. On average, TC accounted for $29 \pm 13 \%$ of the PM10 fraction with OC forming $77 \pm 7 \%$ of this TC. OC was hence an important contributor to $\mathrm{PM}$ mass, as expected from literature (Putaud et al. 2010; Bisht et al. 2015; Chow et al. 2015; Fermo et al. 2015). The increase in the contribution of TC to PM10 (from 24.8 to $33.2 \%$ ) from warm to cold period enhanced its importance as a component of PM10. Negral et al. (2008) found organic matter and elemental carbon representing $18 \%$ of PM10 in southeastern Spain (Cartagena). These researchers discussed the relationship between the carbonaceous fraction and traffic from a highway and coach and train stations close to the sampling station.

During the warm period, RE and ANW episodes were predominant (Fig. 3), constituting the most frequent air-mass origin in this period (32.4 and $24.0 \%$, respectively). In the cold period, however, ANW and AW were the most frequent episodes (29.7 and $26.4 \%$, respectively), highlighting the importance of Atlantic advections. The influence of traffic at the station clearly diminished during these episodes, when OC

Fig. 3 Contribution of air-mass origins over the sampling period

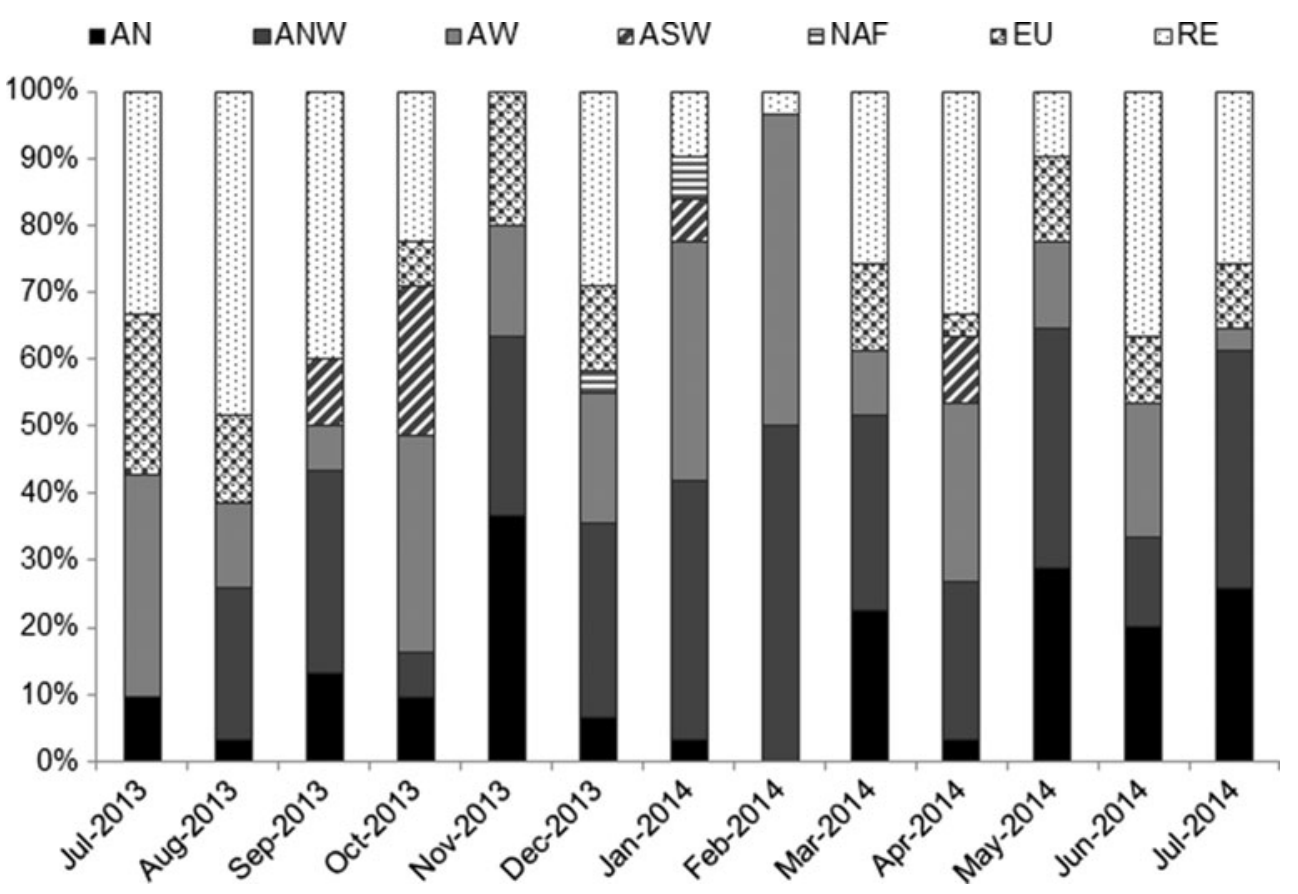


Table 1 Mean, minimum, and maximum values of $\mathrm{OC}, \mathrm{EC}, \mathrm{OC} /$ $\mathrm{EC}, \mathrm{EC} / \mathrm{TC}$ in PM10 during warm and cold periods $(n=52)$ between July 2013 and July 2014

\begin{tabular}{|c|c|c|c|c|c|c|c|c|c|}
\hline & \multicolumn{3}{|c|}{$\begin{array}{l}\text { Entire sampling } \\
\text { period }(n=52)\end{array}$} & \multicolumn{3}{|c|}{$\begin{array}{l}\text { Warm period: } \\
\text { April-September }(n=26)\end{array}$} & \multicolumn{3}{|c|}{$\begin{array}{l}\text { Cold period: October-March } \\
(n=26)\end{array}$} \\
\hline & Mean & Min. & Max. & Mean & Min. & Max. & Mean & Min. & Max. \\
\hline $\mathrm{OC}\left(\mu \mathrm{g} \mathrm{C} / \mathrm{m}^{3}\right)$ & $5.12 \pm 3.62$ & 0.39 & 19.23 & $4.06 \pm 1.65$ & 1.27 & 8.44 & $6.18 \pm 4.66$ & 0.39 & 19.23 \\
\hline $\mathrm{EC}\left(\mu \mathrm{g} \mathrm{C} / \mathrm{m}^{3}\right)$ & $1.45 \pm 0.99$ & 0.22 & 4.96 & $1.05 \pm 0.51$ & 0.36 & 2.61 & $1.85 \pm 1.19$ & 0.22 & 4.96 \\
\hline $\mathrm{OC} / \mathrm{EC}$ & $3.79 \pm 1.58$ & 1.30 & 9.22 & $4.21 \pm 1.52$ & 1.90 & 9.22 & $3.38 \pm 1.55$ & 1.30 & 7.32 \\
\hline $\mathrm{EC} / \mathrm{TC}$ & $0.23 \pm 0.07$ & 0.10 & 0.43 & $0.21 \pm 0.05$ & 0.10 & 0.35 & $0.25 \pm 0.08$ & 0.12 & 0.43 \\
\hline
\end{tabular}

decreased up to $0.39 \mu \mathrm{g} \mathrm{C} / \mathrm{m}^{3}$ and EC up to $0.22 \mu \mathrm{g} \mathrm{C} / \mathrm{m}^{3}$. These values, which occurred on 25 December 2013, might be explained by low traffic flow in the area. Vehicular displacements from the city and its environs to the working and educational centers close to the sampling station were reduced as that day was a national public holiday. According to a nearby traffic measuring point located on the N-632 trunk road, the average daily traffic (ADT) from Monday to Friday was 10, 329 vehicles/day in 2013. On Wednesday, 25 December 2013, the ADT was reduced to 4416 vehicles/day.

In contrast, the highest $\mathrm{TC}$ values were generally reported during RE episodes, exceeding $10 \mu \mathrm{g} \mathrm{C} / \mathrm{m}^{3}$ for OC and $2 \mu \mathrm{g}$ $\mathrm{C} / \mathrm{m}^{3}$ for EC. On these days, PM10 levels were also considerably above the average $\left(19.1 \mu \mathrm{g}\right.$ PM10/m ${ }^{3}$ ), up to $42.6 \mu \mathrm{g}$ PM10/m $\mathrm{m}^{3}$. Higher EC, OC, and PM10 values were expected during RE episodes due to poor air circulation (Negral et al. 2012). Moreover, no precipitation was recorded on these days.

The OC/EC ratio varies daily from 1.30-9.22 (Table 1), with an average of $3.79 \pm 1.58$. This mean value was similar to the results reported by other authors in urban locations or sites influenced by road traffic in Spain $(\mathrm{OC} / \mathrm{EC}=2.3)$, Helsinki $(\mathrm{OC} / \mathrm{EC}=3.23)$, Coimbra $(\mathrm{OC} / \mathrm{EC}=2.75)$, and Delhi (OC/EC = 4.38) (Harrison et al. 1997; Viidanoja et al. 2002; Sánchez de la Campa et al. 2009; Sharma et al. 2014). Road traffic was the most relevant source for the chemical composition of the airborne PM in all those sites. Besides, the lowest $\mathrm{OC} / \mathrm{EC}$ ratios were registered during the cold period, which is frequent in urban areas during days with low photochemical activity when the contributions of secondary OC are less important to the OC aerosol (Pio et al. 2011).

EC and OC concentrations presented a moderate correlation, i.e., $R^{2}=0.46$ (Fig. 5), which improved slightly when it did not pass through the origin $\left(R^{2}=0.53\right)$. The relevance of traffic at the sampling station was demonstrated when days with high traffic flow (i.e., working days) were independently studied. Working days $(n=34)$ were taken into account to discriminate these periods as traffic was markedly lower on weekends and public holidays than on weekdays. In 2013, the ADT was 10,329 vehicles/day from Monday to Friday, 7148 vehicles/day on Saturdays, and 6871 vehicles/day on Sundays. Similar data was registered in 2014 (ADT of 10, 425 vehicles/day from Monday to Friday, 7214 vehicles/day on Saturdays, and 6947 vehicles/day on Sundays). An improvement in the results of this study was shown by the linear relationship between EC and OC $\left(R^{2}=0.74\right)$ (Fig. 5), indicating that road traffic was a major common source. Keuken et al. (2012) also found a different composition in PM10 on Sundays due to reduced traffic flow. Sharma et al. (2014) reported the influence of vehicular emissions on PM10 with a linear trend between $\mathrm{OC}$ and $\mathrm{EC}\left(R^{2}=0.53\right)$.

The influence of traffic on pollution levels was also reproduced via the correlation between $\mathrm{BS}$ and $\mathrm{EC}$, although to a lesser extent than the correlation between $\mathrm{EC}$ and OC, i.e., from $R^{2}=0.49$ (all days) to $R^{2}=0.59$ (working days). BS concentration was calculated on the basis of measured values of
Fig. 4 Variation in TC and precipitation between July 2013 and July 2014

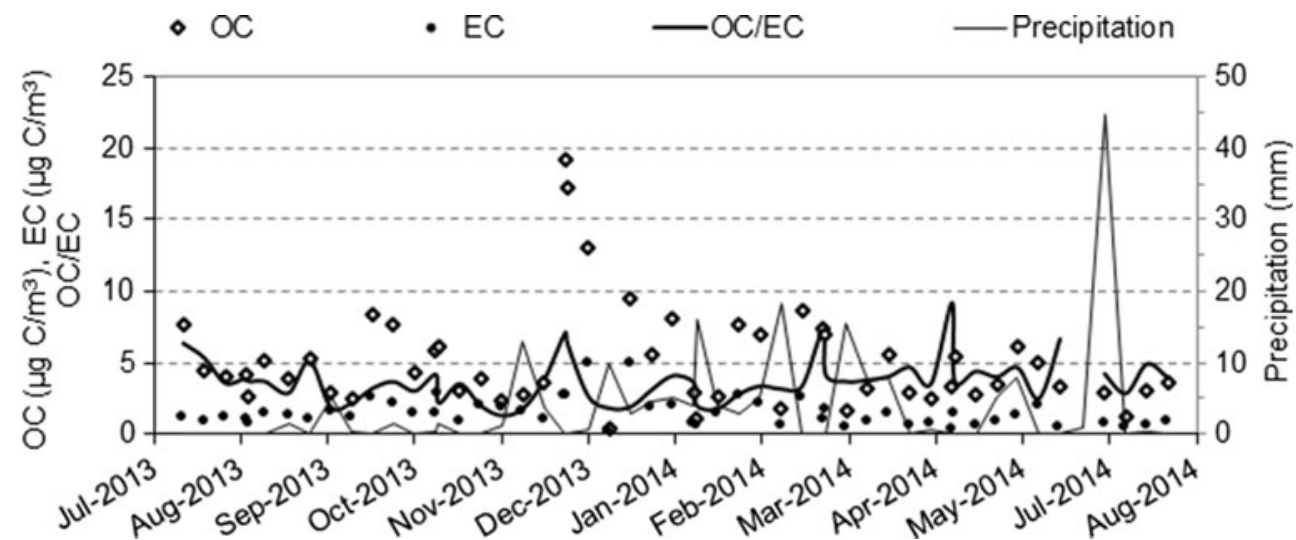


Fig. 5 Comparison of the correlation between EC and OC considering all sampling days $(n=52)$ and only working days $(n=34)$

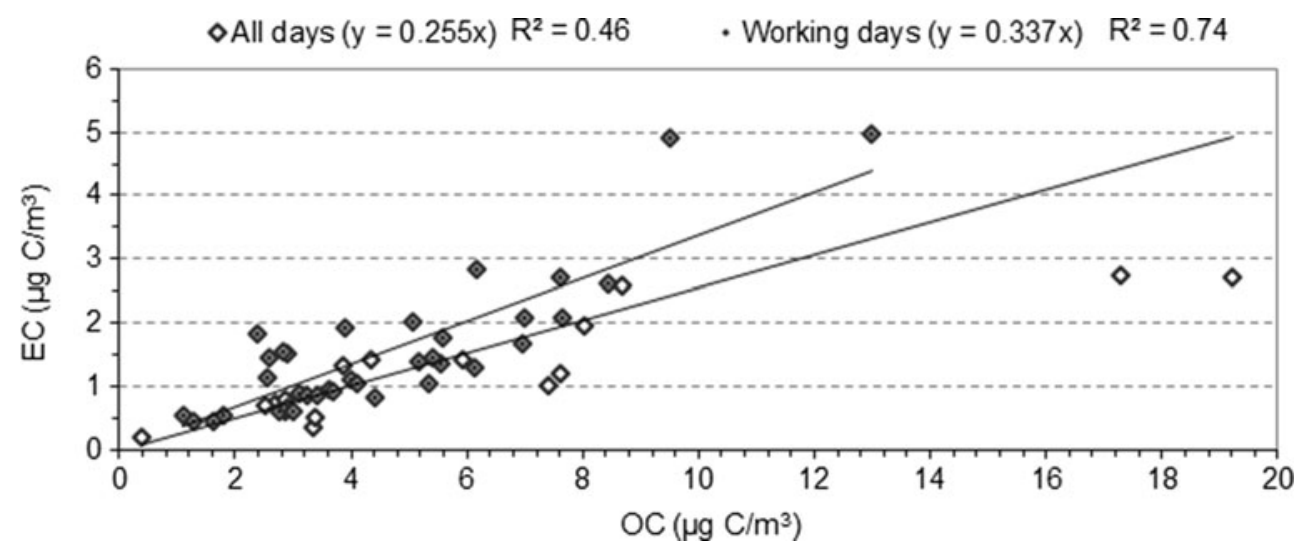

reflectance in agreement with the OECD standard method. The OECD (1964) relates BS with the reflectance of a stain in a filter. Heal and Quincey (2012) reported that the ISO (1993) standard provides an expression to calculate $\alpha$ from reflectance values, which is compatible with the early OECD standard method after applying a scaling factor. The $\alpha$-EC correlation thus provided similar results to the BS-EC correlation, as expected $\left(R^{2}=0.40\right)$, although the effect of excluding the days with low traffic flow was more notable $\left(R^{2}=0.57\right)$.

\section{Elemental carbon and metals}

As stated in the "Introduction" section, the correlation between some metals and EC may indicate that road traffic is a common source. Relevant results were found in $\mathrm{Cu}$ (Fig. 6), in which a linear regression showed its high dependence on EC $\left(R^{2}=0.82\right)$. Sn similarly reproduced this pattern with a good fit $\left(R^{2}=0.79\right)$ (Fig. 6). All data were considered in these relationships, without distinguishing working days. Along these same lines, Pérez et al. (2010) pointed to traffic-related sources for these elements by correlating them with $\mathrm{BC}$ $\left(R^{2}=0.58\right.$ for $\mathrm{Cu}$ and $R^{2}=0.66$ for $\left.\mathrm{Sn}\right)$.

Some traffic tracers presented a better correlation with $\mathrm{Cu}$ than with EC, suggesting a common origin with the former. This was the case of $\mathrm{Sn}$, whose correlation improved from
$R^{2}=0.79$ with EC (Fig. 6) up to $R^{2}=0.91$ with $\mathrm{Cu}$ (Fig. 7), as well as $\mathrm{Ba}\left(\mathrm{EC}-\mathrm{Ba}: R^{2}=0.53 ; \mathrm{Cu}-\mathrm{Ba}: R^{2}=0.69\right)$ and $\mathrm{Sb}$ (EC-Sb: $R^{2}=0.60 ; \mathrm{Cu}-\mathrm{Sb}: R^{2}=0.73$ ) (Fig. 7).

Thorpe and Harrison (2008) reviewed studies of nonexhaust PM from traffic, revealing $\mathrm{Cu}, \mathrm{Sb}, \mathrm{Ba}$, and $\mathrm{Sn}$ as compounds of brakes. Indeed, $\mathrm{Cu}$ and $\mathrm{Sb}$ were presented as reliable tracers of brake wear. The $\mathrm{Cu} / \mathrm{Sb}$ ratio had a mean value of 6.6 (Table 2). Typical reported values of the $\mathrm{Cu} / \mathrm{Sb}$ ratio range between 4.9 and 8 (Alves et al. 2015). Amato et al. (2009) studied PM10 in road dust deposited at an urban background. These authors showed a high correlation between $\mathrm{Cu}$ and $\mathrm{Sb}$ and proposed a diagnostic criterion for brake wear particles: $\mathrm{Cu} / \mathrm{Sb}=7.0 \pm 1.9$. Sternbeck et al. (2002) determined a $\mathrm{Cu} / \mathrm{Sb}$ ratio of $4.6 \pm 2.3$ in tunnels. Nevertheless, the conclusion in both studies was that brake linings were a common source of $\mathrm{Cu}$ and $\mathrm{Sb}$. The $\mathrm{Cu} / \mathrm{Sb}$ ratio of the present study agrees with the criteria established by previous authors. Therefore, brake wear seems to have been a relevant origin for $\mathrm{Cu}$ and $\mathrm{Sb}$ in the present study. According to Grigoratos and Martini (2015), brake linings contain 1-5\% Sb in the form of stibnite $\left(\mathrm{Sb}_{2} \mathrm{~S}_{3}\right)$, which is employed as a lubricant in order to reduce vibrations and improve friction stability. Other possible origins of $\mathrm{Sb}$ are crust and metallurgical processes, although the diagnostic $\mathrm{Cu} / \mathrm{Sb}$ ratios for these origins (125 and 10 , respectively) are markedly different from the $\mathrm{Cu} / \mathrm{Sb}$ ratio of brake wear (Thorpe and Harrison 2008).
Fig. 6 Correlations of $\mathrm{Cu}$ and $\mathrm{Sn}$ with EC

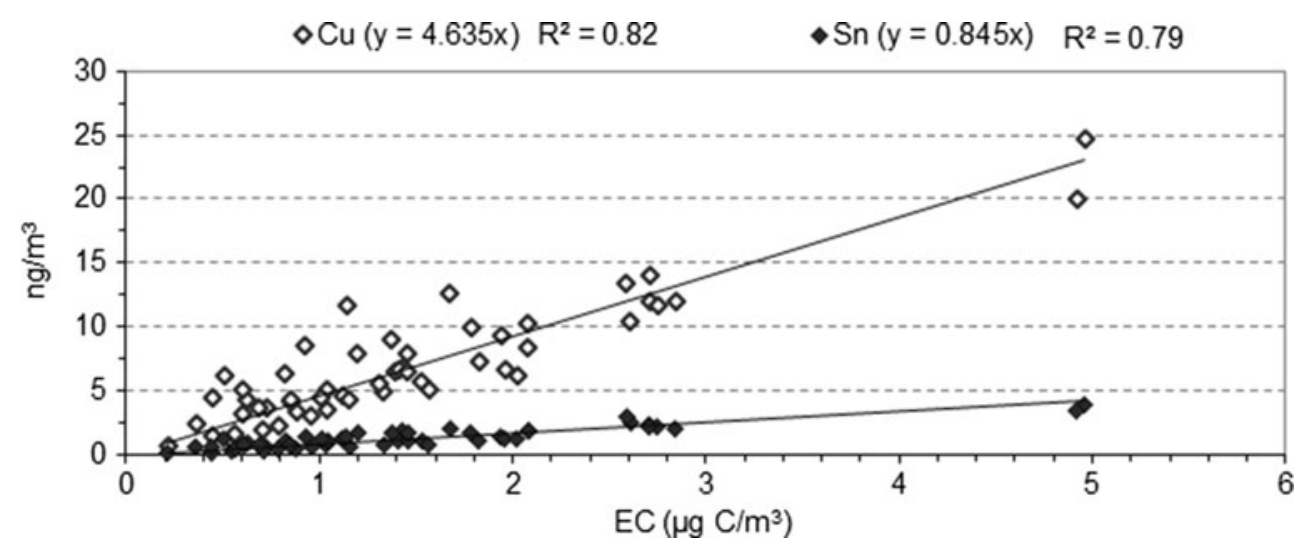


Fig. 7 Correlations of $\mathrm{Sn}, \mathrm{Ba}$, and $\mathrm{Sb}$ with $\mathrm{Cu}$ $\bullet \operatorname{Sn}(y=0.180 x)$

$\square B a(y=0.47 x+1.73)$

$\Delta \mathrm{Sb}(\mathrm{y}=0.11 \mathrm{x}+0.33)$

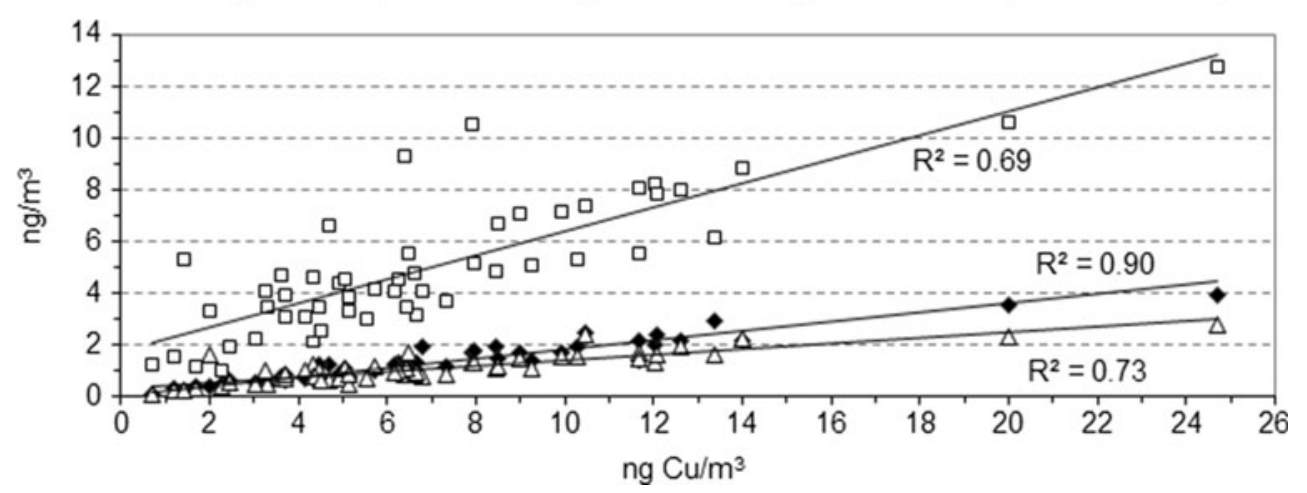

$\mathrm{Cu}, \mathrm{Sb}$, and $\mathrm{Bi}$ were also related to brake abrasion (Minguillón et al. 2012). In fact, a relationship between $\mathrm{Cu}$ and $\mathrm{Bi}$ was found (Table 2). The high ratio between the two was due to the low values of $\mathrm{Bi}$. Ba also correlated with the aforementioned elements (Table 2) and has been associated to brake wear (Garg et al. 2000). Moreover, the $\mathrm{Ba} / \mathrm{Cu}$ ratio $(0.85)$ is close to the mean value determined in tunnels, e.g., $\mathrm{Ba} / \mathrm{Cu}=0.75$ (Sternbeck et al. 2002; Alves et al. 2015). However, the presence of $\mathrm{Bi}$ and $\mathrm{Ba}$ in $\mathrm{PM}$ has also been associated with metallurgical activities and mineral matter from soil, respectively (Querol et al. 2007; RogulaKozłowska et al. 2015). Therefore, other relevant origins of $\mathrm{Bi}$ and $\mathrm{Ba}$ cannot be discarded with the current information.

The aforementioned correlations between these chemical species (i.e., $\mathrm{Cu}, \mathrm{Sn}, \mathrm{Sb}, \mathrm{Ba}$, and $\mathrm{Bi}$ ) stood at a similar degree independently of the traffic flow (e.g., $\mathrm{Cu}-\mathrm{Sn}$ in working days: $R^{2}=0.90(n=35)$ versus in non-working days: $\left.R^{2}=0.93(n=17)\right)$. Thus, a main common origin was gathered. However, the maximum and minimum concentrations of $\mathrm{Cu}, \mathrm{Sn}, \mathrm{Sb}, \mathrm{Ba}$, and $\mathrm{Bi}$ were determined in working and non-working days, respectively. Indeed, their average concentrations were slightly higher during working days, especially in the case of copper (i.e., $7.6 \pm 4.9 \mu \mathrm{g} \mathrm{Cu} / \mathrm{m}^{3}$ in working days

Table 2 Relevant ratios and linear correlation coefficients $\left(R^{2}\right)$ between metals as traffic tracers in PM10 $(n=52)$

\begin{tabular}{lllll}
\hline Metals & $R^{2}$ & \multicolumn{2}{l}{ Ratio } & \\
\cline { 3 - 5 } & & Mean & Min. & Max. \\
\hline $\mathrm{Cu}-\mathrm{Sb}$ & 0.73 & $6.55 \pm 2.00$ & 1.26 & 13.12 \\
$\mathrm{Cu}-\mathrm{Sn}$ & 0.91 & $5.38 \pm 1.02$ & 3.60 & 8.39 \\
$\mathrm{Cu}-\mathrm{Ba}$ & 0.69 & $1.40 \pm 0.47$ & 0.27 & 2.29 \\
$\mathrm{Cu}-\mathrm{Bi}$ & 0.69 & $61.93 \pm 21.45$ & 13.86 & 106.17 \\
$\mathrm{Ba}-\mathrm{Cu}$ & 0.69 & $0.85 \pm 0.51$ & 0.44 & 3.68 \\
$\mathrm{Ba}-\mathrm{Sb}$ & 0.61 & $5.41 \pm 3.88$ & 2.07 & 22.97 \\
$\mathrm{Ba}-\mathrm{Bi}$ & 0.69 & $48.50 \pm 23.35$ & 17.68 & 156.86 \\
$\mathrm{Ba}-\mathrm{Sn}$ & 0.66 & $4.58 \pm 3.03$ & 2.07 & 22.00 \\
\hline
\end{tabular}

versus $5.6 \pm 3.7 \mu \mathrm{g} \mathrm{Cu} / \mathrm{m}^{3}$ in non-working days), pointing to traffic as their relevant source.

Additional data are given in Online Resource 1.

\section{Conclusions}

PM10 levels and the chemical composition of this fraction were determined at a suburban sampling station in the north of Spain. No major seasonal variation was found in PM10 at the site between cold (OctoberMarch) and warm (April-September) periods. Different strategies were implemented to study the influence of traffic in a complex scenario where other anthropogenic sources (i.e., industrial activities) played an important role in air pollution.

The OC/EC ratio was similar to those reported in the literature at urban locations or sites influenced by road traffic. Noteworthy results were found in the correlation between OC and EC $\left(R^{2}=0.46\right)$, which reflected a considerable improvement when considering exclusively days with high traffic flow $\left(R^{2}=0.74\right)$. BS similarly reproduced this pattern, confirming the relevance of carbonaceous particles in PM10. The study of the linear relationships between several metals typically accepted as traffic tracers also led to conclusions in this respect. $\mathrm{Cu}$ and $\mathrm{Sn}$ were mainly emitted by traffic given their high dependence on EC $\left(R^{2}=0.82\right.$ and $R^{2}=0.79$, respectively). Moreover, $\mathrm{Sn}, \mathrm{Sb}, \mathrm{Ba}$, and $\mathrm{Bi}$ presented a stronger correlation with $\mathrm{Cu}$ than with $\mathrm{EC}$, pointing to a common origin for these metals. The $\mathrm{Cu} / \mathrm{Sb}$ ratio was in full agreement with results from other studies, and brake wear may constitute their main source. Bi and $\mathrm{Ba}$ also seemed to have the same origin and were related to $\mathrm{EC}$ and $\mathrm{Cu}$, though to a lesser extent.

As inferred from the relationships and ratios between traffic tracers, non-exhaust emissions could have played a relevant role in PM10. Brake wear was presented as the most likely origin for $\mathrm{Cu}, \mathrm{Sb}$, and $\mathrm{Sn}$. 
Acknowledgments This study was supported by funding from the Principality of Asturias Regional Government for the project: "Particulate matter in the air of Asturias: levels, composition and source contribution" (in Spanish), ref. SV-PA-13-ECOEMP-65. The authors are grateful to NOAA Air Resources Laboratory (ARL) for providing the HYSPLIT model and the READY website (http://www.arl.noaa. gov/ready.html). Acknowledgment is also given to the Traffic Service of Gijón and the Spanish National Meteorological Agency (AEMET) for the information provided. The authors thank the anonymous reviewers who read and improved this manuscript with their comments.

Open Access This article is distributed under the terms of the Creative Commons Attribution 4.0 International License (http:// creativecommons.org/licenses/by/4.0/), which permits unrestricted use, distribution, and reproduction in any medium, provided you give appropriate credit to the original author(s) and the source, provide a link to the Creative Commons license, and indicate if changes were made.

\section{References}

Aldabe J, Elustondo D, Santamaría C, Lasheras E, Pandolfi M, Alastuey A, Querol X, Santamaría JM (2011) Chemical characterisation and source apportionment of PM2.5 and PM10 at rural, urban and traffic sites in Navarra (North of Spain). Atmos Res 102:191-205. doi:10. 1016/j.atmosres.2011.07.003

Alves CA, Gomes J, Nunes T, Duarte M, Calvo A, Custodio D, Pio C, Karanasiou A, Querol X (2015) Size-segregated particulate matter and gaseous emissions from motor vehicles in a road tunnel. Atmos Res 153:134-144. doi:10.1016/j.atmosres.2014.08.002

Amato F, Pandolfi M, Viana M, Querol X, Alastuey A, Moreno T (2009) Spatial and chemical patterns of PM10 in road dust deposited in urban environment. Atmos Environ 43:1650-1659. doi:10.1016/j. atmosenv.2008.12.009

Bisht DS, Srivastava AK, Pipal AS, Srivastava MK, Pandey AK, Tiwari S, Pandithurai G (2015) Aerosol characteristics at a rural station in southern peninsular India during CAIPEEX-IGOC: physical and chemical properties. Environ Sci Pollut R 22:5293-5304. doi:10. 1007/s11356-014-3836-1

Cavalli F, Viana M, Yttri KE, Genberg J, Putaud JP (2010) Toward a standardised thermal-optical protocol for measuring atmospheric organic and elemental carbon: the EUSAAR protocol. Atmos Meas Tech 3:79-89. doi:10.5194/amt-3-79-2010

Chow JC, Yang X, Wang X, Kohl SD, Hurbain PR, Chen LWA, Watson JG (2015) Characterisation of ambient PM10 bioaerosols in a California agricultural town. Aerosol Air Qual Res 15:1433-1447. doi:10.4209/aaqr.2014.12.0313

Draxler RR, Hess GD (1997) Description of the HYSPLIT_4 modeling system. NOAA Tech. Memo. ERL ARL-224, NOAA Air Resources Laboratory, Silver Spring, MD

EEA (2014) Air quality in Europe — 2014 Report. European Environment Agency http://www.eea.europa.eu/publications/air-quality-ineurope-2014. Accessed 26 August 2015

EN 12341:1998 Air quality - determination of the PM10 fraction of suspended particulate matter - reference method and field test procedure to demonstrate reference equivalence of measurement methods, CEN 1998

E-PRTR The European Pollutant Release and Transfer Register. http:// prtr.ec.europa.eu/. Accessed 26 August 2015

European Commission (2008) Directive 2008/50/EC of the European Parliament and of the Council of 21 May 2008 on ambient air quality and cleaner air for Europe. Off J Eur Union L152:1-44
Fermo P, Gonzalez Turrrion R, Rosa M (2015) A new approach to assess the chemical composition of powder deposits damaging the stone surfaces of historical monuments. Environ Sci Pollut R 22:62626270. doi:10.1007/s11356-014-3555-y

Fuzzi S, Baltensperge U, Carslaw K, Decesari S, Denier van der Gon H, Facchini MC, Fowler D, Koren I, Langford B, Lohmann U, Nemitz E, Pandis S, Riipinen L, Rudich Y, Schaap M, Slowik JG, Spracklen DV, Vignati E, Wild M, Williams M, Gilardoni S (2015) Particulate matter, air quality and climate: lessons learned and future needs. Atmos Chem Phys 15:8217-8299. doi:10.5194/acp-15-8217-2015

Garg B, Cadle SH, Mulawa PA, Groblicki PJ, Laroo C, Parr GA (2000) Brake wear particulate matter emissions. Environ Sci Technol 21: 4463-4469. doi:10.1021/es001108h

Gelencsér A (2004) Carbonaceous aerosol, 1st edn. Springer, Dordrecht

Grigoratos T, Martini G (2015) Brake wear particle emissions: a review. Environ Sci Pollut R 22:2491-2504. doi:10.1007/s11356-0143696-8

Harrison RM, Yin J (2008) Sources and processes affecting carbonaceous aerosol in central England. Atmos Environ 42:1413-1423. doi:10. 1016/j.atmosenv.2007.11.004

Harrison RM, Deacon AR, Jones MR, Appleby RS (1997) Sources and processes affecting concentrations of PM10 and PM2.5 particulate matter in Birmingham (U.K.). Atmos Environ 31:4103-4117. doi: 10.1016/S1352-2310(97)00296-3

Heal MR, Quincey P (2012) The relationship between black carbon concentration and black smoke: a more general approach. Atmos Environ 54:538-544. doi:10.1016/j.atmosenv.2012.02.067

Hueglin C, Gehrig R, Baltensperger U, Gysel M, Monn C, Vonmont H (2005) Chemical characterisation of PM2.5, PM10 and coarse particles at urban, near-city and rural sites in Switzerland. Atmos Environ 39:637-651. doi:10.1016/j.atmosenv.2004.10.027

IDEPA (2014) Instituto de Desarrollo Económico del Principado de Asturias http://www.idepa.es/sites/web/idepaweb/productos/cifras/ demografia/index.jsp?section=3. Accessed 30 October 2015

ISO (1993) International Standard ISO 9835:1993 Ambient air-determination of a black smoke index. International Organization for Standardization, Geneva

Keuken MP, Jonkers S, Zandveld P, Voogt M, van den Elshout S (2012) Elemental carbon as an indicator for evaluating the impact of traffic measures on air quality and health. Atmos Environ 61:1-8. doi:10. 1016/j.atmosenv.2012.07.009

Minguillón MC, Querol X, Baltensperger U, Prévôt ASH (2012) Fine and coarse PM composition and sources in rural and urban sites in Switzerland: local or regional pollution? Sci Total Environ 427: 191-202. doi:10.1016/j.scitotenv.2012.04.030

Minguillón MC, Cirach M, Hoek G, Brunekreef B, Tsai M, de Hoogh K, Jedynska A, Kooter IM, Nieuwenhuijsen M, Querol X (2014) Spatial variability of trace elements and sources for improved exposure assessment in Barcelona. Atmos Environ 89:268-281. doi:10. 1016/j.atmosenv.2014.02.047

Negral L, Moreno-Grau S, Moreno J, Querol X, Viana MM, Alastuey A (2008) Natural and anthropogenic contributions to PM10 and PM2.5 in an urban area in the western Mediterranean coast. Water Air Soil Poll 192:227-238. doi:10.1007/s11270-008-9650-y

Negral L, Moreno-Grau S, Querol X, Moreno J, Viana M, GarcíaSánchez A, Alastuey A, Moreno-Clavel J (2012) Weak pressure gradient over the Iberian Peninsula and African Dust Outbreaks: a new dust long-transport scenario. B Am Meteorol Soc 93:11251132. doi:10.1175/BAMS-D-10-05000.1

OECD (1964) Methods of measuring air pollution. Report of working group on methods of measuring air pollution and survey techniques. Organisation for Economic Co-operation and Development, Paris

Pérez N, Pey J, Cusack M, Reche C, Querol X, Alastuey A, Viana M (2010) Variability of particle number, black carbon, and PM10, PM2.5, and PM1 levels and speciation: influence of road traffic 
emissions on urban air quality. Aerosol Sci Tech 44:487-499. doi: $10.1080 / 02786821003758286$

Pey J, Querol X, Alastuey A (2009) Variations of levels and composition of PM10 and PM2.5 at an insular site in the Western Mediterranean. Atmos Res 94:285-299. doi:10.1016/j.atmosres.2009.06.006

Pio C, Cerqueira M, Harrison RM, Nunes T, Mirante F, Alves C, Oliveira C, de la Campa Sánchez A, Artínano B, Matos M (2011) OC/EC ratio observations in Europe: re-thinking the approach for apportionment between primary and secondary organic carbon. Atmos Environ 45: 6121-6132. doi:10.1016/j.atmosenv.2011.08.045

Port of Gijón (2014) Annual Report. Statistic data. https://www. puertogijon.es. Accessed 26 August 2015

Putaud JP, Van Dingenen R, Alastuey A, Bauer H, Birmili W, Cyrys J, Flentje H, Fuzzi S, Gehrig R, Hansson HC, Harrison RM, Herrmann H, Hitzenberger R, Hüglin C, Jones AM, Kasper-Giebl A, Kiss G, Kousa A, Kuhlbusch TAJ, Löschau G, Maenhaut W, Molnar A, Moreno T, Pekkanen J, Perrino C, Pitz M, Puxbaum H, Querol X, Rodriguez S, Salma I, Schwarz J, Smolik J, Schneider J, Spindler G, ten Brink H, Tursic J, Viana M, Wiedensohler A, Raes F (2010) A European aerosol phenomenology - 3: physical and chemical characteristics of particulate matter from 60 rural, urban, and kerbside sites across Europe. Atmos Environ 44:1308-1320. doi:10.1016/j. atmosenv.2009.12.011

Querol X, Viana M, Alastuey A, Amato F, Moreno T, Castillo S, Pey J, de la Rosa J, Sánchez de la Campa A, Artiñano B, Salvador P, García Dos Santos S, Fernández-Patier R, Moreno-Grau S, Negral L, Minguillón MC, Monfort E, Gil JI, Inza A, Ortega LA, Santamaría JM, Zabalza J (2007) Source origin of trace elements in PM from regional background, urban and industrial sites of Spain. Atmos Environ 41:7219-7231. doi:10.1016/j.atmosenv.2007.05.022

Rogula-Kozłowska W, Majewski G, Czechowski PO (2015) The size distribution and origin of elements bound to ambient particles: a case study of a Polish urban area. Environ Monit Assess 187:240. doi:10.1007/s10661-015-4450-5

Salvador P, Artiñano B, Querol X, Alastuey A, Costoya M (2007) Characterisation of local and external contributions of atmospheric particulate matter at a background coastal site. Atmos Environ 41:117. doi:10.1016/j.atmosenv.2006.08.007

Sánchez de la Campa AM, Pio C, de la Rosa JD, Querol X, Alastuey A, González-Castanedo Y (2009) Characterization and origin of EC and OC particulate matter near the Doñana National Park (SW Spain). Environ Res 109:671-681. doi:10.1016/j.envres.2009.05. 002

Schilirò T, Bonetta S, Alessandria L, Gianotti V, Carraro E, Gilli G (2015) PM10 in a background urban site: chemical characteristics and biological effects. Environ Toxicol Phar 39: 833-844. doi:10.1016/j.etap.2015.02.008

Sharma SK, Mandal TK, Saxena M, Sharma RA, Datta A, Saud T (2014) Variation of OC, EC, WSIC and trace metals of PM10 in Delhi, India. J Atmos Sol-Terr Phy 113:10-22. doi:10.1016/j.jastp.2014. 02.008

Sternbeck J, Sjödin Å, Andréasson K (2002) Metal emissions from road traffic and the influence of resuspension - results from two tunnel studies. Atmos Environ 36:4735-4744. doi:10.1016/S13522310(02)00561-7

Thorpe A, Harrison RM (2008) Sources and properties of nonexhaust particulate matter from road traffic: a review. Sci Total Environ 400:270-282. doi:10.1016/j.scitotenv.2008.06. 007

Umlauf G, Christoph EH, Eisenreich SJ, Mariani G, Paradiž B, Vives I (2010) Seasonality of PCDD/Fs in the ambient air of Malopolska Region, southern Poland. Environ Sci Pollut R 17:462-469. doi:10. 1007/s11356-009-0215-4

Viidanoja J, Sillanpää M, Laakia J, Kerminen V-M, Hillamo R, Aarnio P, Koskentalo T (2002) Organic and black carbon in PM2.5 and PM10: 1 year of data from an urban site in Helsinki, Finland. Atmos Environ 36:3183-3193. doi:10.1016/S1352-2310(02) 00205-4

Vodička P, Schwarz J, Cusack M, Ždímal V (2015) Detailed comparison of OC/EC aerosol at an urban and a rural Czech background site during summer and winter. Sci Total Environ 518-519:424-433. doi:10.1016/j.scitotenv.2015.03.029 